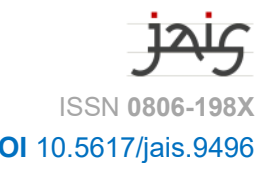

\title{
Dollar Crisis
}

\author{
By WALTER ARMBrust
}

In April three of the four statues of Ramsis from the Abu Simbel Temple depicted on the back of the Egyptian one-Pound ( $1 \mathrm{£E}$ ) bill talk about a rumoured plan to float the Pound (the fourth statue lost his head long ago in an earthquake and remains silent) (YT "Ahmose") [ Inferiority $=$ Superiority (Satire)]. The conversation begins with one of the statues asking another to loan him $5 £$ E. The second statue curtly refuses. The first statue then says, "Guys, what are we going to do? I've heard they're going to float us." The second statue thinks this is nonsense, prompting the first statue to appeal to the third surviving statue. "Say, old guy over there, what do you think about this?" The third statue, looking at a laptop improbably carved into the stone four thousand years ago, becomes alarmed. "It looks like they really are going to float us! ... I can't stand being floated again. No, harām!" The second statue opines that the $£ E$ is actually very strong, and that if they remain patient and wait until the year 2030, as President al-Sisi had recommended, everything will be fine. The first statue is appalled to be told that he has to wait 15 years for an improvement in the situation. "Come on," says the second statue. "You've been sitting here waiting for 4,000 years. What's another 15 years?" But the first statue is fed up. "I've had it. Give me my $5 £$ E and let's get out of here. Enough nonsense." "If I had some I'd give it to you," says his companion." "Same old same old," retorts the first statue. The second statue replies, "Mish $2 \bar{a} d i r$ addīk" (I have nothing to give you), again channelling one of President al-Sisi's most famous utterances.

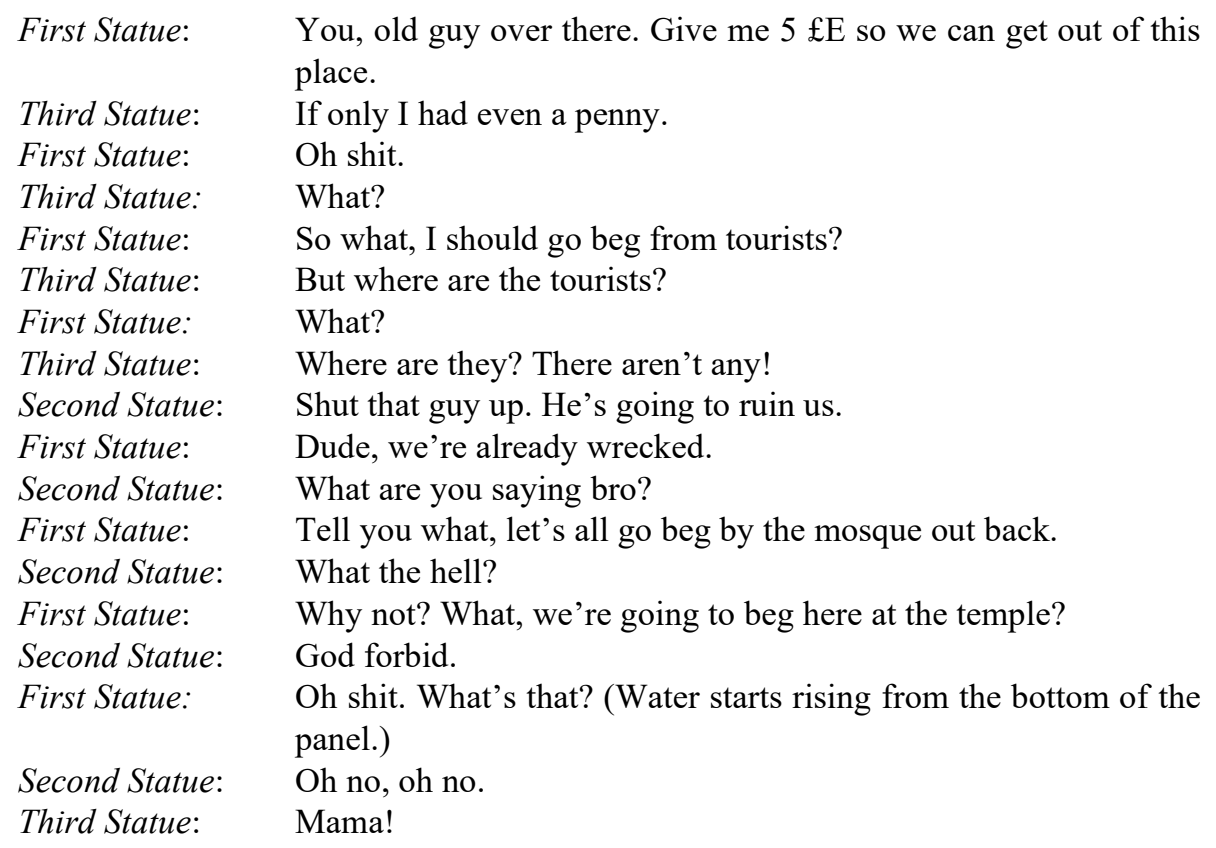




$\begin{array}{ll}\text { First Statue: } & \text { There you go. See? } \\ \text { Second Statue: } & \text { And what did I do to deserve this? } \\ \text { Third Statue: } & \text { (sobbing) Save me! } \\ \text { First Statue: } & \text { You could see this coming. I told you. } \\ \text { Second Statue: } & \text { This isn't right. } \\ \text { Third Statue: } & \text { No, no, I can't swim! Don't float me! No! } \\ \text { First Statue: } & \text { Who's floating? We're drowning! Drowning! }\end{array}$

The conversation of the statues on the back side of the $1 £ \mathrm{E}$ bill is prescient. In April, when rumours of a float are everywhere, the official price of a dollar is $£ \mathrm{E} 8.85$ compared to $£ \mathrm{E}$ 10.50 on the black market (HUȘĀM). By early November, just before the float actually happens, the black market price hovers around $£ \mathrm{E} 18$ per dollar against an official rate that remains at $£$ E 8.85 ('ABD ALLĀH).

But what exactly does "floating the Pound" mean? In the most straightforward sense it means a shift from strict regulation of the exchange rate between the Egyptian Pound and foreign currencies by the Central Bank of Egypt to an unfettered market in foreign exchange rates, in which rates are determined purely by supply and demand. The Central Bank can also opt for limited intervention in currency markets by withholding or releasing foreign currency reserves in order to nudge the exchange rate one way or another (CNN). Foreign exchange rates matter because the Egyptian Pound is not considered a "hard currency," which is to say a currency that is likely to retain its value relative to other currencies because its underlying economy is strong, or at least so large that it cannot be ignored by the rest of the world.

Conventionally global trade across national borders takes place through hard currencies, particularly the US dollar or the European Euro. Egypt must therefore purchase what it needs from abroad not in its own currency, but in dollars, Euros, or other currencies considered "hard." The Egyptian government has an interest in keeping the exchange rate between the Pound and hard currencies stable because a depreciation in the value of the Pound relative to other currencies is inflationary-if purchasing goods from abroad requires more Pounds to buy the necessary dollars, then the local price for those imported goods rises.

Normally the price of the Pound should be kept stable through trade; private businesses would bring in hard currency by selling goods or services, and they would then use this currency to purchase what they need abroad. The government also needs hard currency, which it can bring in, for example, by charging fees for using the Suez Canal, or by taxing foreign companies operating in Egypt. This year, all sources of hard currency, private and public, are reduced from their previous levels. Turmoil from the January $25^{\text {th }}$ Revolution and its aftermath has already hit the tourism sector severely, and then a Russian airplane is blown up in the Sinai, resulting in the deaths of 224 tourists. This devastates the tourism sector [ЛTourist Resorts]. Tourism brings in only 3.4 billion USD this year, down from a preRevolution high of 12.5 billion (ar.wiki). President al-Sisi had promised last year that an expansion of the Suez Canal financed by bonds sold to the public in Egyptian currency would increase Canal revenues from an annual level of 5.3 billion USD in 2015 to 13.2 billion in 2023 (MCD). But Canal revenue actually drops from the level of the previous year (Bidāya). Moreover, hard-currency remittances from Egyptian workers abroad are falling, as is foreign investment ('ASR). 
As all sources of hard currency fall, the Central Bank attempts to prop up the value of the Pound by making foreign reserves available for borrowing by commercial banks. If reserves fall too far then confidence that Egypt's currency is backed by actual assets will be eroded and the exchange value of the Egyptian Pound will fall even further. The Central Bank can only continue pumping hard currency into the Egyptian economy through the kindness of strangers. Or actually, not quite strangers, but rather certain of the oil-rich Gulf Arab states, particularly Saudi Arabia and the United Arab Emirates, but conspicuously not Qatar, which had played the same role during the 12 months of Muhammad Mūrsì's rule. By April it is said that the Gulf has provided 23 billion dollars over the past few years to Egypt in the form of grants, investments, fuel supplies and bank transfers, and that $50 \%$ of the Central Bank's foreign currency reserves consists of transfers from the Gulf (Mișriyyūn). However, other factors affect the Gulf states' willingness to continue propping up the Egyptian Central Bank. Egypt does not see eye to eye with its Saudi patrons with respect to the ongoing civil war in Syria. Dissension comes into the open in early October when Egypt votes with Russia in the United Nations on a peace plan that would leave the Iran-backed Bashshār al-Asad in power (al-MARKAZ al-'Arabī lil-Abhāath). Furious, the Saudis turn off the spigots, for both fuel and money. The price of the Pound slumps from from $£ E 12.80$ to the dollar on the black market in mid-September to around $£ E 18$ to the dollar by the middle of October. The official rate stays at $£ E$ 8.88. Nobody can afford to convert Pounds at the official rate. The floating of the Pound is inevitable.

Float the Pound to its "natural" level, or let the Black market decide: either way, as the Pound declines in value the price of everything imported rises. Wages and income in Egyptian Pounds, however, do not rise nearly as much. In the space between stagnant wages and rising prices Egyptians feel pain. In August, before the float, inflation is at the level of $16.4 \%$ per year (KASSĀB). In November, after the float, the annual inflation rate reaches $20 \%$ $\left(\mathrm{NA}_{\mathrm{FI}} \mathrm{C}^{\mathrm{C}}\right)$. Everyone knows the worst is yet to come. But this year it becomes clear that Egypt lacks self-sufficiency in many crucial fields, and this means that the palpable effect of the dollar crisis is that local demand for a wide range of products must be met through increasingly pricey imports. The dollar crisis manifests itself in a series of other crises-in medicine (NoonPost), energy (YawmSäbi ), many types of food (MANīsī) — even baby milk [ $\neg$ Baby Milk]. A Tuk Tuk driver articulates the public's outrage at the hardship imposed by this rampant inflation in a video interview that swiftly goes viral [ $\nearrow$ Tuk-tuk, $\lambda$ Social Media]. When asked what he is complaining about he explodes:

Let me ask you one question: a state that has a parliament, military and security institutions... how can they let a situation like this happen? Before we had presidential elections we had enough sugar for everyone. We had rice, and we exported it. What happened? Where did it all go, we want to understand. When we watch television Egypt looks like Vienna; we go down into the streets and it's Somalia. For God's sake, tell me what happened, and what's the solution? (YT "Sawwāq")

The official response to the crisis is that Egypt's only possible course of action is to arrange a substantial loan, $\$ 12$ billion to be precise, from the International Monetary Fund. The IMF famously imposes conditions on the recipients of its loans, the most important of which, in this case, is to float the currency of the nation receiving the funds (HusNī). Whether the

jais • 21 (2021) - Themed Section In2016: *93_*98 
purpose of these conditions is to ensure that the funds are used for the benefit of the recipient or, alternatively, to ensure that the recipient of the loan can effectively repay the lender (even at the cost of actually damaging the recipient's economy for most people), is a matter of dispute (TALAB). President al-Sisi, for his part, emphasizes that the purpose of the loan is to correct economic imbalances that have built up over the past sixty years of military rule [ЛThe Voice from Above], ignoring the fact that he is extending military rule for an indeterminate period. But he asserts that the chaos of the January $25^{\text {th }}$ Revolution and the heavy burden of paying public-sector salaries are particularly to blame for Egypt's economic woes. He emphasizes that the burden of reforming Egypt's economy must be borne by all (YT "Radd"), ignoring the fact that it will be disproportionately carried by the vast majority of Egyptians who have no access to hard currency.

Karam, a Șa îdi interviewed in a café and subsequently the subject of a viral video [ $\lambda$ Social Media], has other ideas about the dollar crisis. He does not believe that the dollar crisis exists:

There's no problem, no crisis, nothing at all. It's just that the nations of the demonsduwal al-sufliyyin - are coming to get Egyptian Pounds because they can get stuff with

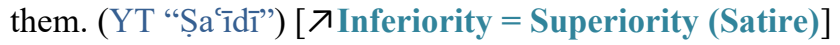

The interviewer does not quite comprehend what Karam means by al-sufliyyin, but it finally dawns on him that Karam means literally al-'ălam al-sufli, the underworld. There may not be much demand for Egyptian Pounds by those who possess hard currency in our world, or at least not at the official rate of exchange; but 'afärīt wa-shayātīnn, demons and devils, value the Pound greatly in the underworld. The interviewer is sceptical, so Karam has to give him a demonstration. He spreads a large pile of Egyptian five Pound notes on the table in front of him and covers them with his wool scarf. Karam then softly sings a patriotic song. After a while he stops singing and removes his scarf from the pile of money on the table. Presto! The five Pound notes have all been transformed into generous piles of dollars! The crowd in the café bursts into applause.

Karam: Here you go. The dollars that you're saying are in crisis, and you're worried, and afraid of dollars [holding one up to the camera]

Interviewer: I don't understand how this can be.

Karam: Here they are. I was right in front of you. I didn't do a thing. Here are your dollars. There's no crisis. That's the value of Egyptian money. I challenge America and whoever is behind America, with the Egyptian Pound.

Interviewer: Thank you Karam.

And so the dollar crisis is solved. Or perhaps it has been fake news from the beginning [ภTrue vs. False].

\section{Related Entries}

ARRAYs - Baby Milk $\downarrow$ Social Media $\downarrow$ Tourist Resorts $\downarrow$ Tuk-tuk $\downarrow$ The Voice from Above

CODES - True vs. False

jais • 21 (2021) - Themed Section In2016: *93-*98 
CODES COLLAPSED - Inferiority $=$ Superiority (Satire)

\section{References}

'ABD AllĀH, Aḥmad. "Si'r al-dūlār al-yawm al-arbi ầ' 2 nūfambir 2016 muqābil al-gunayh al-mișri fî 'l-sūq al-sawdā'." Nujūm Mișriyya, November 2, 2016, <https://www.nmisr.com/finance/ dollar211-2016> (accessed July 27, 2018).

[ar.wiki] = "Al-Siyāḥa fī Miṣr". 2016. Wīkībīdiyā, <https://tinyurl.com/ydxredhv> (accessed July 27, 2018).

'AsR, Khālid. "Si'r al-dūlār al-yawm wa'l-asbāb al-ḥaqīqiyya warā’a azmat al-khaḍrā̄ fì Miṣr watawaqqu'āt al-khubarā’ lil-fatra al-muqbila." Nujūm Miṣriyya, August 27, 2016, <https://tinyurl. com/y9whym6s $>$ (accessed July 28, 2018).

[Bidāya] = "Infūgrāf: Inkhifāọ īrādāt qanāt al-Suways țiwāl shuhūr 2016 muqārana bi-2015 bi-nisba 4.5\%." al-Bidāya, January 2, 2017, <http://albedaiah.com/news/2017/01/02/127837> (accessed July 28, 2018).

[CNN] = "Mādhā ya'nī ta'wīm al-gunayh al-mișrīe" CNN bil-'Arabī , November 3, 2016, <https:// arabic.cnn.com/business/video/2016/11/03/v11282-buss-031116-egyptian-pound-liberalizationexplainer> (accessed July 30, 2018).

ḤusĀM, Hiba. "Si'r al-dūlār fî̀ 'l-bunūk wa'l-sūq al-sawdā' al-yawm al- arbi 'ä’ 27-4-2016." al-Yawm al-Säbic, April 27, 2016, <https://tinyurl.com/y9bfphpd> (accessed on July 27, 2018).

HUUSNĪ, Khālid. "6 ishtirāțāt yakhshāhā al-mișriyyūn fĩ qarḍ şundūq al-naqd al-duwalī." al-Aswāq al'Arabiyya, July 31, 2016, <https://tinyurl.com/y9tdasce> (accessed July 28, 2018).

KASSĀB, Bīsān. "Al-rukūd 'alà 'l-abwāb: Mas'ūl ḥukūmī yatawaqqa' tarāju' al-ṭalab al-mahallī 2 illā 3\% bi-sabab 'al-qīma al-muḍafa'." Madā Miṣr, October 11, 2016, <https://tinyurl.com/ycs84b8c> (accessed July 28, 2018).

MANīsī, Usāma. 2016. "Farag 'Āmir: Naqș al-sukkar yaựac al-șinācāt al-ghadhā’iyya fī azma țāhinina." al-Bursa, November 17, <https://alborsanews.com/2016/11/17/931248> (accessed July 28, 2018).

al-MARKAZ al-'Arabī lil-Abhāth. "al-Khilāfăt al-mișriyya - al-sa'ūdiyya: Azma 'ābira am iftirāq istrātìjī?" al-Mudun, October 27, 2016, <https://tinyurl.com/yd5z7bm7> (accessed July 28, 2018).

$[\mathrm{MCD}]=$ "Al-Sīsī min 'alà matn 'al-Maḥrūsa' yaftatị 'qanāt Suways al-jadīda'." MCD-Mūnt(i) Kārlū al-Duwaliyya, August 6, 2016, <https://tinyurl.com/ych2xk3t> (accessed July 27, 2018).

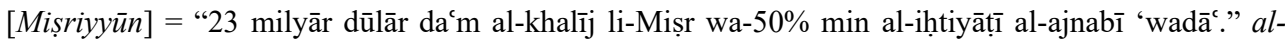
Mișriyyūn, April 23, 2016, <https://tinyurl.com/y9lxprfz> (accessed July 28, 2018).

NĀFI', Asmā'. "Khubarā’’: Mu'addalāt al-taḍakhkhum taqūd Miṣr lil-iflās." Miṣr al-'Arabiyya, December 11, 2016, <https://tinyurl.com/y914drho> (accessed July 28, 2018).

[NoonPost $]=$ "Maqālāt: Kayfa tafāqamat azmat al-dawā' fī Mișr mu’akhkharan?" N[ūn] Bōst, December 22, 2016, <https://www.noonpost.org/content/15793> (accessed July 28, 2018.

ṬALAB, Aḥmad. 2016. "Maqālāt: Mā sirr ișrār Miṣr 'alà qarḍ şundūq al-naqd al-duwalī?" N[ūn] Bōst, October 19, <https://www.noonpost.org/content/14601> (accessed July 28, 2018).

[YawmSābi ${ }^{\prime}$ = "D. Muḥammad Gamāl Kafāfī yaktub: Miṣr lā tu’ānī min azmat țāqa bal azmat kafă’at istakhdāmihā." al-Yawm al-Sābic, September 1, 2016, <https://tinyurl.com/y94slscd> (accessed July 28, 2018).

[YT "Ahmose"] = "Al-Malik Ahmus". Youtube Video, 2016, <https://www.youtube.com/watch?v= HapX6KW1hJg> (accessed July 27, 2018).

[YT "Radd"] = "Radd al-ra'̄̄s al-Sīsī 'alà irtifāc as'ār al-kahrabā" wal-qarḍ min șundūq al-naqd alduwalī". Youtube video, uploaded on August 13, 2016, <https://www.youtube.com/watch?v= TfFdrUrM-yU> (accessed July 28, 2018).

jais 21 (2021) - Themed Section In2016: *93-*98 


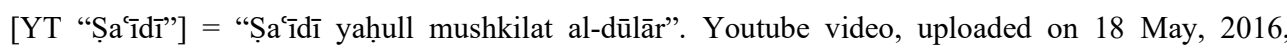
$<$ https://www.youtube.com/watch?v=9jjDsmuZqIY> (accessed July 28, 2018).

[YT "Sawwāq"] = "Sawwāq tūk-tūk yulakhkhiṣ ḥāl Miṣr fî 3 daqā̄iq, ma'a 'Amr al-Laythī, barnāmij Wāḥid min al-nās." Youtube video, uploaded on November 10, 2016, <https://www.youtube.com/ watch? $\mathrm{v}=\mathrm{VbaHv} 9 \mathrm{nUs}-\mathrm{E}>$ (accessed July 28, 2018).

«alter.armbrust@sant.ox.ac.uk 